\title{
IMPACT OF RET PROTO-ONCOGENE ANALYSIS ON THE CLINICAL MANAGEMENT OF MULTIPLE ENDOCRINE NEOPLASIA TYPE 2
}

\author{
Sergio Pereira de Almeida Toledo, Marcelo Augusto Cortina Gonçalves dos Santos \\ Rodrigo de Almeida Toledo, and Delmar Muniz Lourenço Júnior
}

Toledo SPA, Cortina MA, Toledo RA, Lourenço, DM. Impact of RET proto-oncogene analysis on the clinical management of multiple endocrine neoplasia type 2. Clinics. 2006:61(1);59-70.

Multiple endocrine neoplasia type 2 (MEN2) is an autosomal dominant disease characterized by the presence of medullary thyroid carcinoma, primary hyperparathyroidism, and pheochromocytoma. Multiple endocrine neoplasia type 2 is still an underdiagnosed, or late-diagnosed condition in many areas of the world. Since 1993, when the first missense RET proto-oncogene (RET) mutations were reported in MEN2, up to 46 different RET-causing disease mutations have been described. Since a strong genotype-phenotype correlation exists for MEN2, the detection of RET mutations has produced a major impact in early recognition and treatment of MTC and MEN2. Presently, RET mutation analysis should be performed for all MEN2 cases and their at-risk familial relatives. Further, prophylactic total thyroidectomy is indicated in all cases harboring activating gametic RET mutations. In most RET mutation carriers, prophylactic total thyroidectomy is indicated at ages as early as a few months to 4 years of age, promoting longer survival and improvement of quality of life or even definitive cure. We discuss the large impact of RET protooncogene analysis on the clinical management of MEN2 and the role of early RET molecular DNA diagnosis in providing clinicians and surgeons with valuable information that enables them to indicate early total thyroidectomy.

KEYWORDS: Endocrine Neoplasia. MEN2. RET proto-oncogene. Pheochromocytoma. Hyperparathyroidism. HSCR. MTC. FMTC.

\section{INTRODUCTION}

Multiple endocrine neoplasia type 2 (MEN2) is associated with the occurrence of 3 inherited endocrine tumors: medullary thyroid carcinoma (MTC), primary hyperparathyroidism (HPT), and pheochromocytoma (PHEO). Multiple endocrine neoplasia type 2 is transmitted by an autosomal dominant gene, which imposes the need of genetic screening of all family members at risk having inherited a predisposition to this condition. The 3 neoplasias involved are derived from neural crest cells, such as $\mathrm{C}$ thyroid cells, parathyroid oxyphilic and

Genetic Endocrinology Unit (LIM-25), Internal Medicine Department, São Paulo University Medical School, São Paulo/SP, Brazil.

Email: cortina_marcelo@hotmail.com

Received for publication on July 04, 2005.

Accepted for publication on November 11, 2005. chief cells, and chromaffin cells of the adrenal medulla. Sympathetic, parasympathetic, and enteric ganglia and the urogenital tract have been also reported as expressing high levels of several hormonal and nonhormonal substances produced by the affected glands. ${ }^{1-13,18-20}$

Despite all efforts performed towards the management of MEN2, this condition is still an underdiagnosed, or latediagnosed disease in many areas of the world. Presently, molecular DNA diagnosis to identify RET mutations is mandatory for all MEN2 cases and for their relatives at risk for a predisposition to MEN2. This diagnostic procedure is turning out to be a fundamental tool in early MEN2 diagnosis, enabling correct therapeutic surgical management. ${ }^{12}$

\section{MOLECULAR MEDICINE}

In 1986, with the identification of DNA polymorphisms 
in chromosome 10 in large MEN2 genealogies, the study of the RET proto-oncogene gained further interest. ${ }^{10}$ Transfection DNA studies of several MTC tumors revealed important foci of proliferation in NIH-3T3 cells, represented by the presence of different genetic DNA sequences. ${ }^{10}$ Among these sequences, one - RET (rearranged during transfection) - was present in all tumor specimens. Soon afterwards, the RET sequence was localized in the chromosome band 10q11.2. ${ }^{10,13-15}$ The RET gene has $60 \mathrm{~kb}$ of the human genome spread through 21 exons, with 60 to 287 base pairs (bp), having a $24 \mathrm{~kb}$ intron between the first and second exons and encoding a protein of approximately 1,100 amino acids. ${ }^{13,16}$ In 1993, Mulligan et al and Donnis-Keller et al (1993) identified the first missense mutations in the RET extracellular RETdomain in patients with MTC and MEN2. ${ }^{21,22}$

RET is the only gene that has been associated with MEN2, and gametic mutation in this proto-oncogene has been extensively studied. Management of MEN2 using DNA sequencing information represents an excellent example of how molecular DNA diagnosis may improve clinical management. ${ }^{1,3,6,8,13,23}$

\section{CLASSIFICATION}

Table 1 summarizes the accepted classification of MEN2, as suggested by the international consensus on MEN. ${ }^{1}$ This classification is based on clinical pictures of affected MEN2 patients.

Table 01 - Phenotypic classification of MEN2 (Adapted from ref. ${ }^{1,13}$ )

Multiple endocrine neoplasia2A (1): Families with medullary thyroid carcinoma, pheochromocytoma and hyperparatyroidism phenotype

Multiple endocrine neoplasia2A (2): Families with medullary thyroid carcinoma and pheochromocytoma phenotype in at least one at risk relative

Multiple endocrine neoplasia2A (3): Families with medullary thyroid carcinoma and hyperparatyroidism phenotype in at least one at risk relative

Multiple endocrine neoplasia2B: Families with medullary thyroid carcinoma, associated or not with pheochromocytoma and muscular/ skeletal abnormalities and mucosal neuromas

Familial medullary thyroid carcinoma: Families only with medullary thyroid carcinoma phenotype in at least four at risk relatives

Others: Families with less than four relatives with medullary thyroid carcinoma, pheochromocytoma and hyperparatyroidism phenotype. In this group are included partially documented families

Thyroid cancer is a relatively rare event comprising $0.6 \%$ and $1.6 \%$ of all carcinomas affecting men and women, respectively. ${ }^{24}$ Medullary thyroid carcinoma comprises $10 \%$ of all thyroid cancers, presenting as sporadic
(75\%) or inherited (25\%) forms. Multiple endocrine neoplasia type 2 has an estimated prevalence of 1 in 30,000 individuals, and more than $90 \%$ of RET carriers will develop MTC. ${ }^{1,8,25}$ The international consensus on MEN estimates that $95 \%$ of MEN2 patients have a detectable RET mutation. Mutations in exons 10,11 , and 16 are present in $90 \%$ to $95 \%$ of cases. ${ }^{1}$

Multiple endocrine neoplasia type 2A comprises $75 \%$ of all MEN2 cases. In MEN2A, MTC is prevalent in almost $100 \%$ of patients, whereas PHEO (50\%) and HPT $(20 \%-30 \%)$ are less frequently expressed. The mean age of clinical diagnosis of MEN2A is 20 to 40 years, but this should soon decrease, as new young RET mutation carriers are recognized and treated earlier in life. ${ }^{8}$

The familial form of MTC (FMTC) comprises $20 \%$ of all MEN2 cases, and it is characterized by the presence of MTC in the absence of both PHEO and HPT, both in index cases and affected family members. Usually in FMTC, MTC tends to present less aggressive behavior and better prognosis than in MEN2A or MEN2B. ${ }^{13,26}$

Five percent (5\%) of MEN2 cases have the phenotype of MEN2B, the most aggressive form of MTC. This form is characterized by the association of MTC, PHEO, marfanoid habitus, and mucosal neuromas (lips, tongue, eyebrows, and intestinal tract), whereas the presence of HPT is very rare..$^{13}$ Medullary thyroid carcinoma in MEN2B usually appears very early, usually before 12 months of age. ${ }^{8,27}$

\section{MEDULLARY THYROID CARCINOMA (MTC)}

Affected families usually have several members with MTC. ${ }^{8}$ Ever since molecular diagnosis has been performed, increasing incidences and prevalences of inherited forms of MTC have been reported. Familial forms of MTC are constitutive events that lead to bilateral, multicentric thyroid cancer. Among several bioactive substances secreted by thyroid $\mathrm{C}$ cells, calcitonin is the most representative and the best tumor marker for MTC. ${ }^{4,9}$

Thyroid C-cell hyperplasia is usually the earlier histologic abnormality in MTC and represents a premalignant stage. It initially occurs as small foci, progressing to nodular diffuse hyperplasias that may evolve to focal and finally to metastatic MTC. ${ }^{28-32}$ The usual clinical presentation of MTC is a solitary thyroid nodule. ${ }^{28-32}$ At the stage of palpable thyroid nodules, MTC measures at least $1 \mathrm{~cm}$, and $50 \%$ of patients already have local neck lymph node metastases and more rarely lung, liver, and bone metastases. ${ }^{33,34}$ It has been suggested that routine calcitonin measurements should be performed in all patients with solid thyroid nodules, since this procedure would permit presurgical diagnosis of the sporadic form of MTC as well 
as in familial MTC index cases, permitting the establishment of an adequate surgical plan. ${ }^{35,36}$ Fine-needle biopsy followed by immunocytochemistry for calcitonin is also helpful for the presurgical diagnosis of MTC.,11,12,37-40 Total thyroidectomy associated with extensive resection of neck lymph nodes is the only effective treatment for MTC, as the tumor is usually resistant to iodo-, chemo-, and radiotherapy. ${ }^{1,11,12}$ In early diagnosed cases, C-cell hyperplasia is predominant, and neck lymph node resection may be less massive. ${ }^{1,11,12}$

Genetic sequencing of MTC has resulted in dramatically lower mortality rates. Before Genetic sequencing was available, mortality rates for MEN2 were up to $20 \%$, whereas after RET mutation analysis, mortality has been as low as $5 \%$ in some samples. ${ }^{1}$

\section{PHEOCHROMOCYTOMA (PHEO)}

Five to fifteen percent of all PHEOs are associated with MEN2, and most of them (90\%) are benign. Pheochromocytomas associated with MEN2 are usually located on the adrenals (90\%), but extra-adrenal cases have been reported. ${ }^{1}$ Most tumors (50\%-80\%) are bilateral. Patients with PHEO/ MEN2 present a pretumoral stage characterized by nodular or diffuse hyperplasia of chromaffin adrenal cells. ${ }^{1,41-48}$ The diagnosis of PHEO is usually accomplished after the recognition of MTC (40\%-50\%); however, it may occur before or synchronously with MTC diagnosis. ${ }^{1,41}$ Thus, RET analysis should be considered in all PHEO cases. ${ }^{1}$

Notably, the possibility of an undiagnosed PHEO must be ruled out in all MTC patients before surgery to avoid the intrasurgical risk of an adrenal hypertensive crisis. Since a contralateral tumor may appear many years after the first diagnosis, PHEO/MEN2 patients need long-term follow-up. Image studies with MIBG (metaiodobenzylguanidine) and serum/urinary measurements of catecholamines are useful in this task. ${ }^{1,41}$

\section{HYPERPARATHYROIDISM (HPT)}

Hyperparathyroidism associated with MEN2 (HPT/ MEN2) results from a hyperplastic process of parathyroid chief cells involving the 4 parathyroid glands. In most HPT/ MEN2 cases (68\%), associated adenomas have been also reported. ${ }^{1,49}$ Primary HPT associated with MEN2 is a mild disease presenting slightly elevated concentrations of PTH and calcium. Several measurements may be needed to enable the biochemical diagnosis of HPT. ${ }^{1}$ In early-diagnosed MEN2 cases, HPT tends to be asymptomatic. Late-diagnosed cases are usually symptomatic, and renal stones are usually reported as the first clinical symptom. Osteoporo- sis may occur in such cases. During neck surgery for MTC in MEN2 cases, enlarged parathyroid glands are frequently found. ${ }^{1}$

Two surgical approaches have been used for HPT in MEN2. In the first approach, the 4 parathyroid glands are removed and half of a gland is implanted in the nondominant forearm. In the other approach, 3 1/2 glands are removed. Postsurgical euparathyroidism is less often achieved in HPT/MEN2 than in sporadic primary HPT, and its recurrence rate may be high. ${ }^{1,49}$ When HPT is present, parathyroidectomy and total thyroidectomy are usually performed during the same surgical stage. ${ }^{50}$

Prior to 1993, i.e., before the advent of genetic analysis for RET, all individuals at risk for MTC, PHEO, and HPT underwent annual screening (from 6 years of age). This procedure usually included measurements of basal and stimulated calcitonin, serum and urinary catecholamines, calcium, and PTH. RET genetic analysis is indicated for all patients with MTC or PHEO. ${ }^{1}$ In apparently sporadic HPT, in the absence of other clinical suspicion for hereditary MEN2, analysis for RET is not usually performed. ${ }^{1}$

\section{HIRSCHSPRUNG DISEASE (HSCR)}

A nonendocrine entity such as congenital megacolon or Hirschsprung disease (HSCR) has been described in association with gametic inactivating RET mutations and MEN2 cases. This disorder is due to an embryonic defect in the enteric nervous system. In HSCR associated with MEN2, myenteric and submucosal plexi are affected in extensive areas of the distal enteric tube. Most patients present with intestinal obstruction and constipation. Colectomy is frequently performed at early ages in order to correct intestinal transit. ${ }^{31,51}$

\section{MOLECULAR ASPECTS}

The RET proto-oncogene encodes for a tyrosine kinase cell membrane receptor. The extracellular domain of this protein is rich in cysteine residues, and it is encoded by the first 10 exons of RET. Exon 11 encodes for the transmembrane domain, and the 2 intracellular domains of the protein are encoded by 10 other exons. , $36,52,53^{-53}$

The RET extracellular domain includes coding for a cadherin-binding site that is important in intercellular signaling. Extracellular cysteines play an important role in receptor dimerization. At least 10 RET isoforms have been reported as result of 5' and 3' splicing of exon 21; however, their physiological function still partially unknown. ${ }^{8,36,53}$

The protein encoded by $R E T$ plays an important role 
in embryologic migration and development of neural crestderived cells, such as thyroid $\mathrm{C}$ cells, chromaffin adrenal cells, sympathetic, parasympathetic, and enteric ganglia cells, as well as in urogenital tract. ${ }^{13}$ The RET protooncogene is also expressed in parathyroid cells derived from branchial arches. Binding proteins such as GDNF (glial cell line-derived neurotrophic factor) and its receptor, GFR $\alpha-1$ (GDNF family receptor alpha one) interact with the RET-encoded extracellular protein, promoting cell survival of central and peripheral neurons. The RET protooncogene also plays an essential role in renal and enteric neural development. ${ }^{13,54,55}$

Once coupled, ligands and their respective receptors give rise to a ligand-receptor complex that promotes RET receptor monomer dimerization through disulfite bonds. Intracellular tyrosine residues are self-phosphorylated. This process is followed by a complex signaling pathway in which mitotic-activating protein kinases (MAPKs) amplify signaling pathways to cell nuclei, promoting cell mobility and survival. ${ }^{6,35,56}$

The same dimerization process occurs independently of ligand binding when activating RET germline mutations (constitutive mutation) are present in the RET extracellular domain, favoring the development of the neoplastic phenotypes. RET mutations encode for the intracellular protein that leads to disturbances in the substrate catalytic core affinity, favoring the appearance of the neoplastic process. ${ }^{6,35,56}$

Biochemical and transfection studies of tyrosine kinase have revealed differential RET expressions at the cell membrane level. Thus, cysteine residues next to the 5' region (such as mutant codons 609 and 611) present lower protein expression compared to codon 634 mutations, located next to the transmembrane domain. The potency of cell neoplastic transformation of codon 634 RET mutations is clearly higher than that occurring in codons 609 and 611 . This finding may be due to modulation of expression of mature RET-encoded protein receptors at the cell membrane, where most of the RET-encoded protein expression occurs. ${ }^{56,57}$ Thus, most patients with MEN2 who harbor RET 634 mutations will have thyroid, adrenal, and parathyroid tumors, whereas patients with 609 or 611 mutations will present only thyroid cancer. Further, tissue-specific sensitivity may also be modulated by codon-specific RET mutations. Tissue sensitivity is therefore high in thyroid tissue, intermediate in the adrenals, and low in parathyroid glands. ${ }^{3}$ These observations may also explain why activating RET mutations are usually associated with MEN2, whereas inactivating RET mutations are associated with HSCR. Mutations in codons 618 and 620 usually result in RET-encoded receptor amounts sufficient to transform thy- roid and possibly adrenal cells, but insufficient to produce disturbances in normal intestinal gangliogenesis. Hirschsprung disease may be considered a polygenic disease, because RET, GDNF, endothelin receptor-2 genes, and genes located at $9 \mathrm{q} 31$ and $22 \mathrm{q} 11$ bands are involved. ${ }^{6,8}$

\section{GENOTYPE-PHENOTYPE CORRELATIONS}

\section{Multiple endocrine neoplasia type 2A (MEN2A)}

The genotype-phenotype correlations in MEN2 are summarized in Table 2. The vast majority of MEN2A cases (98\%) harbors a missense RET mutation, primarily in exon 10 and 11 and in codons 609, 611, 618, 620, 630, and 634, which comprise a small 25-amino-acid domain. ${ }^{3}$ Rarely, small insertions in codons 635 and 637 have been reported. Codon 634 is involved in $85 \%$ of MEN2A mutations; $52 \%$ of them have a Cys634Arg mutation, and $26 \%$ present the Cys634Tyr mutation. Further, MTC tumor aggressiveness induced by these 2 mutations differ: metastases tend to be more frequent and early in Cys634Arg cases, as compared to Cys634Tyr cases. ${ }^{1,13,58,59}$

In relatives of patients presenting an increased incidence of HPT and the absence of PHEO, a 12 bp duplication was found between codons 634 and 635, corresponding to 4 amino acids and co-segregated with a Cys634Arg mutation. ${ }^{8,13}$ Recently, Nunes et al, of our laboratory, described a case with double RET mutations (Val648Ile/ Cys634Arg). ${ }^{52,60}$ In this family, 2 siblings were Val648Ile carriers and so far have presented neither clinical nor biochemical abnormalities compatible with MEN2A. The other 2 affected siblings presented the usual Cys634Arg RET mutation and early classical MTC presentation. The father presented a rare phenotype of MEN2A associated with an ectopic ACTH-producing PHEO. He was an obligatory carrier of the double RET mutation. The MEN2A in this specific case had a relatively mild presentation. ${ }^{52,60}$

Mutations in the RET intracellular protein receptor domain RET in codons 790 and 804 are rarely associated with MEN2A. Mutations associated with codon 804 are frequent in FMTC. In most of these cases, thyroid tumor tends to present a late onset, slow course, and low aggressiveness, when compared to phenotypes presenting RET extracellular-domain mutations. These patients may exhibit incomplete neoplastic transformation induced by the 804 mutation; however, aggressive MTC tumors and even death due to MTC have been reported in cases harboring codon 804 mutations. ${ }^{8,61}$

Hirschsprung disease has been described in association with MEN2A or FMTC cases that are associated with mutations primarily in codons $609,611,618$, and $620 .^{8,62,63}$ 
Table 2 - Multiple endocrine neoplasia type 2 (MEN2) genotype-phenotype correlations (Adapted from ref..$^{13}$ )

\begin{tabular}{|c|c|c|c|c|c|}
\hline Exon & Affected Codon & $\begin{array}{c}\text { Nucleotides } \\
\text { (wild-type } \rightarrow \text { mutant) }\end{array}$ & $\begin{array}{c}\text { Amino acid } \\
\text { (wild-type } \rightarrow \text { mutant) }\end{array}$ & Phenotype & MEN2 cases $(\%)$ \\
\hline 8 & $\begin{array}{c}532,533,534 \\
533\end{array}$ & $\begin{array}{c}\text { Ins AGG AGT GTG } \\
\text { GGC-TGC }\end{array}$ & $\begin{array}{c}\text { Ins Glu Glu Cys } \\
\text { Gly-Cys }\end{array}$ & $\begin{array}{c}\text { FMTC / HSCR } \\
\text { FMTC }\end{array}$ & Rare \\
\hline 10 & $\begin{array}{l}609 \\
611\end{array}$ & $\begin{array}{c}\text { TGC-CGC } \\
\text { TGC-GGC } \\
\text { TGC-TAC } \\
\text { TGC-AGC } \\
\text { TGC-CGC } \\
\text { TGC-TAC } \\
\text { TGC-TTC } \\
\text { TGC-TGG } \\
\text { TGC-AGC } \\
\text { TGC-CGC } \\
\text { TGC-GGC } \\
\text { TGC-TAC } \\
\text { TGC-TCC } \\
\text { TGC-TTC } \\
\text { TGC-AGC } \\
\text { TGC-CGC } \\
\text { TGC-GGC } \\
\text { TGC-TAC } \\
\text { TGC-TCC } \\
\text { TGC-TTC } \\
\text { TGC-TGG }\end{array}$ & $\begin{array}{l}\text { Cys-Arg } \\
\text { Cys-Gly } \\
\text { Cys-Tyr } \\
\text { Cys-Ser } \\
\text { Cys-Arg } \\
\text { Cys-Tyr } \\
\text { Cys-Phe } \\
\text { Cys-Trp } \\
\text { Cys-Ser } \\
\text { Cys-Arg } \\
\text { Cys-Gly } \\
\text { Cys-Tyr } \\
\text { Cys-Ser } \\
\text { Cys-Phe } \\
\text { Cys-Ser } \\
\text { Cys-Arg } \\
\text { Cys-Gly } \\
\text { Cys-Tyr } \\
\text { Cys-Ser } \\
\text { Cys-Phe } \\
\text { Cys-Trp }\end{array}$ & $\begin{array}{c}\text { MEN2A / FMTC / HSCR } \\
\text { MEN2A / FMTC }\end{array}$ & $0-1$ \\
\hline 11 & $\begin{array}{c}630 \\
634 \\
\\
\\
635,636,637,638 \\
637,638,639 \\
648\end{array}$ & $\begin{array}{c}\text { TGC-TAC } \\
\text { TGC-TCC } \\
\text { TGC-TTC } \\
\text { TGC-AGC } \\
\text { TGC-CGC } \\
\text { TGC-GGC } \\
\text { TGC-TAC } \\
\text { TGC-TCC } \\
\text { TGC-TTC } \\
\text { TGC-TGG } \\
\text { Ins CG AGC TGT GCC } \\
\text { Ins TGC CGC ACG } \\
\text { GTC-ATC }\end{array}$ & $\begin{array}{c}\text { Cys-Tyr } \\
\text { Cys-Ser } \\
\text { Cys-Phe } \\
\text { Cys-Ser } \\
\text { Cys-Arg } \\
\text { Cys-Gly } \\
\text { Cys-Tyr } \\
\text { Cys-Ser } \\
\text { Cys-Phe } \\
\text { Cys-Trp } \\
\text { Ins Thr Ser Cys Ala } \\
\text { Ins Cys Arg Thr } \\
\text { Val-Ile }\end{array}$ & $\begin{array}{l}\text { MEN2A / FMTC } \\
\text { MEN2A } \\
\text { MEN2A / FMTC } \\
\text { MEN2A / FMTC } \\
\text { MEN2A / FMTC } \\
\text { MEN2A } \\
\text { MEN2A }\end{array}$ & $\begin{array}{l}80-90 \\
80-90 \\
\text { Rare }\end{array}$ \\
\hline 13 & $\begin{array}{l}768 \\
790 \\
791\end{array}$ & $\begin{array}{l}\text { GAG-GAC } \\
\text { TTG-TTC } \\
\text { TTG-TTT } \\
\text { TAT-TTT }\end{array}$ & $\begin{array}{l}\text { Glu-Asp } \\
\text { Leu-Phe } \\
\text { Leu-Phe } \\
\text { Tyr-Phe }\end{array}$ & MEN2A / FMTC & Rare \\
\hline 14 & 804 & $\begin{array}{l}\text { GTG-ATG } \\
\text { GTG-TTG }\end{array}$ & $\begin{array}{l}\text { Val-Met } \\
\text { Val-Leu }\end{array}$ & MEN2A / FMTC & $0-1$ \\
\hline 15 & $\begin{array}{l}883 \\
891\end{array}$ & $\begin{array}{l}\text { GCT-TTT } \\
\text { TCG-GCG }\end{array}$ & $\begin{array}{l}\text { Ala-Phe } \\
\text { Ser-Ala }\end{array}$ & $\begin{array}{c}\text { MEN2B } \\
\text { MEN2A / FMTC }\end{array}$ & Rare \\
\hline 16 & $\begin{array}{l}918 \\
922\end{array}$ & $\begin{array}{l}\text { ATG-ACG } \\
\text { TCC-TAC }\end{array}$ & $\begin{array}{l}\text { Met-Thr } \\
\text { Ser-Tyr }\end{array}$ & $\begin{array}{c}\text { MEN2B / HSCR } \\
\text { MEN2B }\end{array}$ & $\begin{array}{l}3-5 \\
\text { Rare }\end{array}$ \\
\hline
\end{tabular}

MEN2A: Multiple endocrine neoplasia type 2A; MEN2B: Multiple endocrine neoplasia type 2B; FMTC: Familial medullary thyroid carcinoma; Ins: Insertion

FAMILIAL MEDULLARY THYROID CARCINOMA (FMTC)

Most FMTC cases (85\%) present RET mutations in exons 10 and 11. The Cys618Ser genotype is found in 33\% of cases; the Cys634Tyr genotype is found in 30\% cases; whereas, the Cys634Arg genotype is rarely associated with this phenotype. ${ }^{1,8}$ Mutations in codons 609,611 , and 620 and those of Glu768Asp, Val804Leu, and Val804Met occurring in tyrosine kinase domains are accepted to be related to FMTC, even though they may also occur in MEN2A. Other mutations in RET tyrosine kinase domains, such as in codons 790, 791, and 891, have been reported. ${ }^{1,8,57}$

Less frequently, hot spots and mutations, such as those in codons $630,790,791,891$, and a 12 bp duplication be- 
tween codons 634 and 635, have been reported in FMTC families, associated with an indolent form of MTC. ${ }^{8,64}$

Additionally, a 9 bp duplication in RET exon 8 creating a new cysteine residue in the extracellular portion of the RET protein receptor was reported in a FMTC family, possibly associated with HSCR. The affected case did not present germline mutations in exons $10,11,13,14$, or 15 or somatic mutations in exons $11,13,15$, and 16 , suggesting the neoplastic activity of this mutation. ${ }^{26}$

Recently, a new exon 8, Gly533Cys RET mutation was reported in 76 FMTC carriers belonging to a family of Spanish extraction in which 229 individuals were at risk. ${ }^{65}$

\section{Multiple endocrine neoplasia type 2B (MEN2B)}

A RET intracellular tyrosine kinase domain mutation, Met918Thr, has been reported in 95\% of MEN2B cases. ${ }^{56}$ In 4 families with MEN2B from Germany, United Kingdom, and Australia, an Ala883Phe substitution in exon 15 was described, comprising $4 \%$ of all MEN2B phenotypes reported to date. ${ }^{8,13,56}$ Some rare mutations have been described, such as Ser922Tyr and a double mutation in codon 804 and Tyr806Cys occurring in the same allele, which was detected in a patient with MEN2B. ${ }^{13}$

Genotype-phenotype correlations in MEN2 have a major and immediate impact in clinical medicine, since genetic testing may differentiate RET carriers from noncarriers. RET carriers should undergo total thyroidectomy at ages that depend on the mutated codon, ${ }^{1,67}$ following the MEN consensus (Table 3). Conversely, noncarriers of the RET mutation should be excluded from annual clinical follow-up, an expensive and stressing procedure for patients. In skillful surgical hands, the risks of neck surgery are minimal even in children. False positives in genetic testing are exceedingly low. ${ }^{1,10}$ All these data have generated an international consensus on MEN regarding which MTC patients should undergo surgery at ages preferably less than 5 years, depending on the mutated codon ${ }^{1,67}$ (Table 3). At the time of writing, molecular DNA diagnosis in MEN2 has become an important tool to a) confirm clinical and laboratory diagnosis of MTC; b) identify as early as possible mutant RET carriers in premalignant stages of the disease; and c) identify noncarrier family members and rule them out for clinical follow-up. ${ }^{33}$

\section{MODIFIER GENES IN RET EXPRESSION}

Transgenic animal models expressing RET mutation are used to better address the question of MEN2 MTC tumor aggressiveness. Medullary thyroid carcinoma occurs in transgenic lines with analogous pathology to that seen in
Table 03 - Surgical management of multiple endocrine neoplasia 2 based on international multiple endocrine neoplasia consensus (Adapted from ref. ${ }^{1}$ )

Risk 3 level: Highest risk of development of an aggressive and early form of medullary thyroid carcinoma. Children with multiple endocrine neoplasia 2B or mutation carriers in codons 883,918 or 922 , should be submitted to total thyreoidectomy during the first six months of life, preferentially a the first month as microscopic medullary thyroid carcinoma with metastases may occur in the first months of life. Total thyreoidectomy should be performed in association with an extensive ressection of the neck lymph nodes, mainly including central neck lymph nodes.

Risk 2 level: High risk to present an aggressive form of medullary thyroid carcinoma. Children carrying RET mutation in codons $611,618,620$ or 634 should be submitted to total surgery before 5 years of age. Total thyreoidectomy should be performed in association with removal of thyroid posterior capsule and dissection of central lymph nodes.

Risk 1 level: Moderate risk to develop aggressive forms of medullary thyroid carcinoma. Children carrying mutations in codons 609, 768, 790, 791804 or 891 should be also submitted to total thyreoidectomy. There are three alternatives related to ages for surgical procedures. First, some authors indicate patients should be operated before age 5, as in risk 2 level. Others suggest 10 years of age as a cut-off for surgical indication. The third alternative is waiting for abnormal basal or stimulated calcitonin values for indicating surgery. Biological behaviors of these tumors are variable, but frequently present a late and indolent evolution. It is worthwhile to note that metastases or death were reported in patients carrying all these genotypes.

patients with MEN2. When the transgene codon 634 mutation was introduced into 4 different genetic backgrounds (BALB/c, C57BL/6J, FVB/N and CBA/ca), 65\% of all animals developed MTC, showing incomplete penetrance. None of the FVB/N transgenic progeny developed MTC, $14 \%$ of transgenic progeny BALB/c, $64 \%$ of C57BL/6J, and $98 \% \mathrm{CBA} / \mathrm{ca}$ mice developed thyroid tumors by 10 months of age, indicating that incomplete tumor penetrance could be modulated by genetic background. Furthermore, tumors in the $\mathrm{CBA} / \mathrm{ca}$ and $\mathrm{C} 57 \mathrm{BL} / 6 \mathrm{~J}$ mice were significantly larger than those in BALB/c transgenic mice. These results are relevant to human MEN2 disease, because this model system may be used to study genes modifying thyroid tumor penetrance in this dominantly inherited human cancer syndrome. ${ }^{68}$

\section{ROUTINE PROCEDURES IN MOLECULAR RET DIAGNOSIS}

Investigators working on studies dealing with humans should follow the Helsinque decisions; thus, before collecting blood samples for DNA analysis, projects should be approved by local ethic committees, and patients involved in research projects should sign a written informed consent.

For genomic DNA extraction, a salting-out method is indicated since it is a simple, low-cost procedure. ${ }^{69}$ For ampli- 
CLINICS 2006;61(1):59-70

Impact of ret proto-oncogene analysis on the clinical management of multiple endocrine neoplasia type 2

Toledo SPA et al.

(a) $\mathrm{T}$ to $\mathrm{C}$ substitution (TGC-CGC) in codon 634 (exon 11) in RET protooncogene, leading to a Cys634Arg mutation

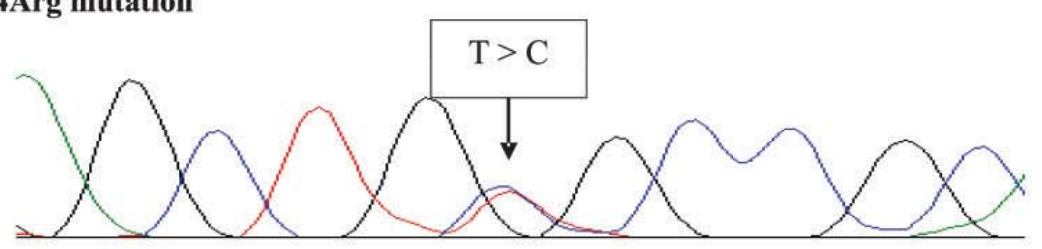

(b) $\mathrm{T}$ to $\mathrm{C}$ substitution(TGC-CGC) in codon 620 (exon 10) in RET protooncogene, leading to a Cys620Arg mutation

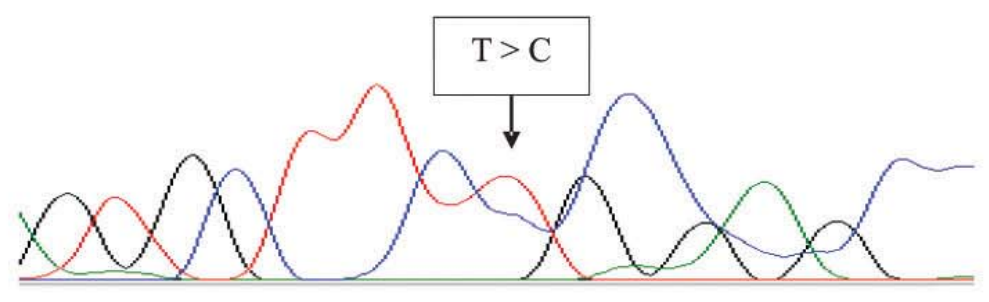

(c) G to A substitution (GTG-ATG) in codon 804 (exon 14) in RET protooncogene, leading to a Val804Met mutation.

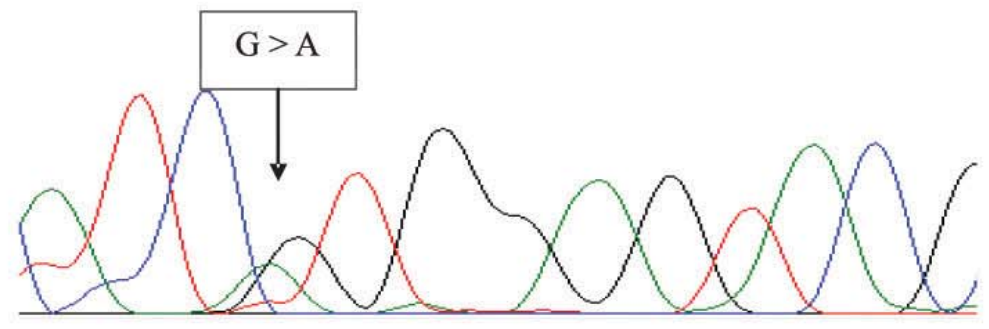

(d) $\mathrm{T}$ to $\mathrm{C}$ substitution (ATG-ACG) in codon 918 (exon 16) in RET protooncogene, leading to a Met918Thr mutation

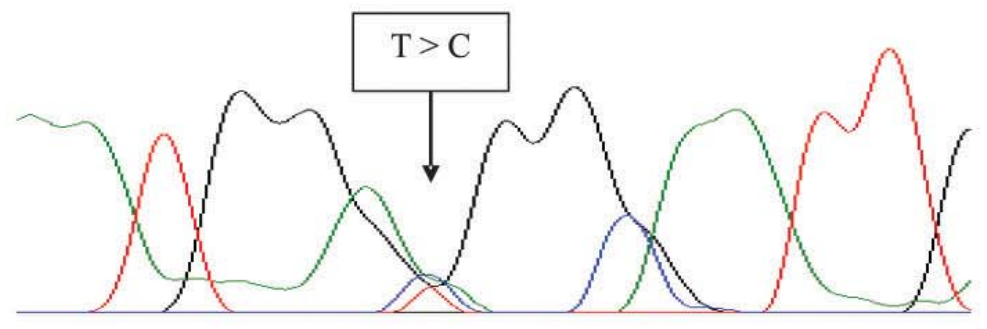

(e) $\mathbf{G}$ to A substitution (GTC-ATC) in codon 918 (exon 11) in RET protooncogene, leading to a Val648Ile mutation

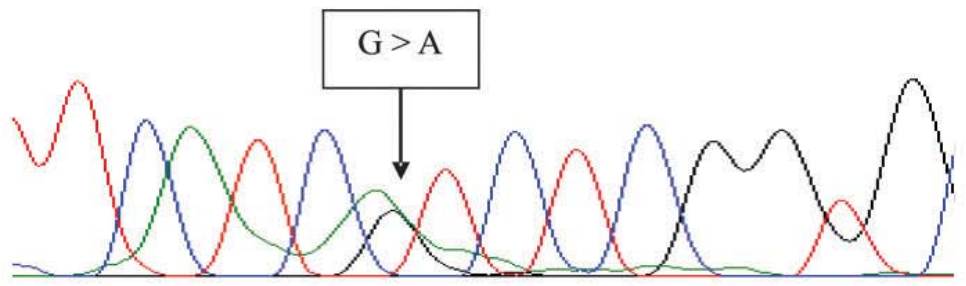

Figure 1 - Electropherograms showing five different types of RET mutations in MEN2, using a DNA sequencer (ABI 310 DNA Sequencer - Applied Biosystems, USA)

65 
fication of genomic DNA, fragments of interest are usually amplified using the polymerase chain reaction (PCR) strategy. ${ }^{70}$ Primers should contain flanking sequences of intronexon boundaries for adequate RET proto-oncogene analysis, and if a laboratory chooses the DGGE (denaturing gradient gel electrophoresis) strategy for screening mutation analysis, primers may also contain a 50bp GC-clamp coupled in one of the sequences. ${ }^{71-73}$ The presence of adequate amplified sequences are confirmed using runs in $1 \%$ agarose gel electrophoresis stained with ethidium bromide. After obtaining PCR products, direct sequencing analysis (the goldstandard method for RET mutation diagnosis) should be performed in all MEN2 index cases. Once the genotype of the RET mutation in the index case is known, it may be used as intrafamilial positive control. For at-risk family members, screening methods may be used. In this latter alternative, it is possible to use DGGE, single-strand conformation polymorphism (SSCP) or restriction enzyme approaches. ${ }^{72-77}$ The DGGE and SSCP techniques are based on differential migration mobilities in polyacrylamide gel. Thus, applying these techniques, it is possible to discriminate between mutant carriers and noncarriers. Different electrophoretic migration patterns are influenced by denaturant substances, such as urea and formamide (in DGGE) or heteroduplex formation (in SSCP). Particularly when screening large MEN2 families, these methods are very useful; for instance, using DGGE, one might analyze 16 exons in 24 hours. Restriction enzymes may possibly be useful in genetic screening for RET mutations, as mutations create or destroy restriction sites recognizable by endonucleases. However, this method should only be applied to confirm DGGE or SSCP findings, considering that interferences may occur as follows: a) inadequate recognition of restriction site and consequently no defined band in agarose gel electrophoresis or b) incomplete discrimination of amplified sequences with similar base pair sizes. ${ }^{77,78}$

Using direct genetic sequencing analysis (the goldstandard method), DNA fragments of interest are sequenced by enzymatic or chain termination, as described by Sanger in $1977 .{ }^{71}$ In this technique, each primer must be added separately to sense and missense reaction tubes, with a commercial buffer (Big Dye Terminator Cycle Sequencing, Applied Biosystems, Foster City, USA) and processed in a thermocycler. After the sequencing reaction, samples are purified with isopropanol and ethanol and diluted in blue dextran buffer with deionized formamide. The sequencing products are then denatured at $90{ }^{\circ} \mathrm{C}$ for 2 minutes, imme- diately cooled, and applied into a specific electrophoresis polymer for the DNA sequencer. Using these procedures, good reproducibility is usually obtained, avoiding the need of a confirmation reaction. Figure 1 illustrates examples of electropherograms showing MEN-2 RET mutations.

\section{CONCLUSIONS}

Before RET molecular diagnosis was possible, first-degree relatives of MEN2 patients (who have a 50\% chance of being carriers) were clinically and biochemically followed up every 12 months for MTC, PHEO, and HPT. Individuals had to be annually evaluated from 6 years of age on. Thus, basal and stimulated calcitonin serum levels were measured in these individuals, as well as serum PTH, calcium, and serum/urinary cathecolamines. ${ }^{8,22,67}$ The sensitivity of these tests was variable, and as a consequence, MTC was usually diagnosed late. This prolonged follow-up was expensive; individuals at risk were maintained in a stressing condition; survival rates were diminished, and cure was almost never achieved due to late MEN2 diagnosis and high prevalence of lymph node metastases, ${ }^{79,80}$

At the time of writing, because almost $95 \%$ of affected MEN2 patients harbor a mutation, genetic diagnosis of MEN2 has become a great success story in the management of patients that are RET mutation carriers. ${ }^{67,81}$ Direct DNA sequencing is of course the gold-standard method for RET mutation analysis and should be performed routinely in all index cases and possibly in all suspected cases. Alternatively, once the presence of a RET mutation is ascertained, screening methods may be used in analyzing family members at risk. Whatever DNA method is used, early RET mutation analysis provides information to clinicians and surgeons allowing them to make adequate surgical decisions. As a consequence of these procedures, mortality rates in MEN2 have dropped from up to $20 \%$ in 1993 to $5 \%$ currently. ${ }^{1}$ Finally, early RET mutation analysis should be performed in all MTC and PHEO cases, as suggested by the MEN consensus. ${ }^{1}$

\section{AKNOWLEDGMENTS}

We thank Papaiz group for supporting this research, aiming to bring to society a faster, safe, and accurate diagnosis of multiple endocrine neoplasias. We also thank all the staff of the Endocrine Genetics Unit (http:// medicina.fm.usp.br/ueg) for the support. 


\section{RESUMO}

Toledo SPA, Cortina MA, Toledo RA, Lourenço, DM. Impacto da análise do proto-oncogene RET na conduta clínica da neoplasia endócrina múltipla tipo 2. Clinics. 2006:61(1);59-70.

A neoplasia endócrina múltipla tipo 2 (NEM2) é caracterizada pela ocorrência do carcinoma medular de tireóide (CMT), hiperparatiroidismo primário (HPT) e feocromocitoma (FEO). ${ }^{1-12}$ Desde 1993, quando as primeiras mutações do tipo missense no proto-oncogene RET (RET), associadas a NEM2 foram identificadas, 46 diferentes mutações causadoras de doenças foram descritas. ${ }^{13-17}$ Como há uma forte correlação genótipo-fenótipo na NEM2, a detecção de mutações no RET adquiriu grande impacto no tratamento precoce do CMT e NEM2. A NEM2 persiste como uma doença subdiagnosticada e/ou tardiamente diagnosticada em várias áreas geográficas do globo. A aná- lise de mutações do RET deve ser realizada em todas os casos de NEM2 e atualmente, a tireoidectomia total profilática é indicada para todos os indivíduos portadores de mutações no RET. ${ }^{1}$ Para a grande maioria dos portadores de mutações gaméticas ativadoras no RET este procedimento cirúrgico é indicado nos primeiros anos de vida, promovendo melhora na qualidade de vida, aumento da sobrevida ou mesmo levando à cura definitiva. ${ }^{1}$ Discutimos nesta revisão, o impacto da análise do proto-oncogene RET na conduta clínica da neoplasia endócrina múltipla tipo 2 . Além disso, o diagnóstico molecular do RET fornece à clínicos e cirurgiões a mais valiosa das informações, permitindo indicação de tireoidectomia total profilática.

UNITERMOS: Neoplasia Endócrina. NEM2. Protooncogene RET. Feocromocitoma. Hiperparatireoidismo. HSCR. CMT. CMT-F.

\section{REFERENCES}

1. Brandi ML, Gagel RF, Angeli A, Bilezikian JP, Beck-Peccoz P, Bordi C, et al. CONSENSUS: Guideline for diagnosis and therapy of MEN type 1 and type 2. J Clin Endocrinol Metab. 2001;86:5658-71.

2. Gagel RF. The impact of gene mapping techniques on the management of multiple endocrine neoplasia type 2. Trends Endocr Metab. $1991 ; 2: 19-25$.

3. Marx SJ. Molecular genetics of multiple endocrine neoplasia types 1 and 2. Nature. 2005;5:367-75.

4. Gimm O. Multiple Endocrine Neoplasia Type 2: Clinical Aspects. In: Dahia PLM, Eng C. Genetic Disorders of Endocrine Neoplasia. 1st ed. Philadelphia: Front Horm Res Basel Karger; 2001. p.103-30.

5. Toledo SPA, Abelin NMA, Ezabella MCL, Hayashida CY, Dahia PM. Neoplasias Endocrinas Múltiplas. In: Wajchenberg BL. Tratado de Endocrinologia Clínica. $1^{\text {o }}$ ed. São Paulo: Roca; 1992. p.943-64.
6. Mulligan LM. Multiple Endocrine Neoplasia Type 2: Molecular Aspects. In: Dahia PLM, Eng C. Genetic Disorders of Endocrine Neoplasia. 1st ed. Philadelphia: Front Horm Res Basel Karger; 2001. p.81-102.

7. Ezabella MCL, Hayashida CY, Abelin NMA, Toledo SPA. Neoplasias Endócrinas Múltiplas. In: Medeiros-Neto G. Moléstias Hereditárias do Sistema Tireoideano. $1^{\circ}$ ed. São Paulo: Roca; 1996. p.225-42.

8. Eng C. RET proto-oncogene in the development of human cancer. J Clin Oncol. 1999;17:390-93.

9. Aliepoulios MA, Rose EH. Specific localization of calcitonin activity in humans' thyroid glands. In: Calcitonin Proceedings of the Second International Syposium. 2nd ed. London: Heinemann; 1970 p.295-300.

10. Gagel RF. Editorial: RET proto-oncogene mutations and endocrine neoplasia - A story interwined with neuronal crest differentiation. Endocrinology. 1996;137:509-11. 
11. Block MA, Jackson CE, Tashjian AH Jr. Management of occult medullary thyroid carcinoma evidenced only by serum calcitonin levels elevations after apparently adequate neck operation. Arch Surg. 1978;113:368-72.

12. Wells SAJr, Franz C. Medullary carcinoma of the thyroid gland. World J Surg. 2000;24:952-6.

13. Hoff AO, Cote GJ, Gagel RF. Multiple endocrine neoplasias. Annu Rev Physiol. 2000;62:377-400.

14. Takahashi M, Buma Y, Iwamoto Y, Ikeda H, Hiahi H. Cloning and expression of RET proto-oncogene encoding a tyrosine kinase with two potential transmembrane domains. Oncogene. 1988;3:571-8.

15. Takahashi M, Buma Y, Hiahi H. Isolation of RET proto-oncogene DNA with an amino-terminal signal sequence. Oncogene. 1989;4:805-6.

16. Kwok JB, Gardner E, Warner JP, Ponder BAJ, Mulligan LM. Structural analysis of the human RET proto-oncogene using exon trapping. Oncogene. 1993;8:2575-82.

17. Mulligan LM, Eng C, Healey CS, Calyton D, Kwok JBJ, Gardner E, et al. Specific mutations of the RET proto-oncogene are related to disease phenotype in MEN2A and FMTC. Nat Genet. 1994;6:70-4.

18. Hansford J, Mulligan LM. Multiple endocrine neoplasia type 2 and RET: from neoplasia to neurogenesis. J Med Genet. 2000;37:817-27.

19. Peczkowska M, Januszewicz A. Multiple endocrine neoplasia type 2 . Familial Cancer. 2005;4:25-36.

20. Teh BT. Multiple endocrine neoplasia. Journal of Internal Medicine. 2003;253:588-89.

21. Mulligan LM, Kwok JB, Healey CS, Elsdon MJ, Eng C, Gardner E, et al. Germ-line mutations of the RET proto-oncogene in multiple endocrine neoplasia type 2A. Nature. 1993;363:458-60.

22. Donnis-Keller H, Dou S, Chi D, Carlson KM, Toshima K, Lairmore TC, et al. Mutations in RET proto-oncogene are associated with MEN2A and FMTC. Hum Molec Genet. 1993;2:851-56.

23. Jimenez C, Gagel RF. Genetic testing in endocrinology: lessons learned from experience with multiple endocrine neoplasia type 2 (MEN2). Growth Horm \& IGF Res. 2004;14:S150-57.

24. Magalhães PKR, Castro M, Elias LLK, Maciel LMZ. Carcinoma Medular de Tireóide: da Definição às Bases Moleculares. Arq Bras Endocrinol Metab. 2003;47:515-28.

25. Maia FFR, Júnior HJ, Araújo LR. Neoplasia Endócrina Múltipla tipo 2 - Manejo Diagnóstíco e Terapêutico. Arq Bras Endocrinol Metab. 2002;46:606-10

26. Pigny P, Bauters C, Wemeau JL, Houcke ML, Crepin M, Caron P, et al. A novel 9-base pair in RET exon 8 in familial medullary thyroid carcinoma. J Clin Endocrinol Metab. 1999;84:1700-04.

27. Brauckhoff M, Gimm O, Weiss C L, Ukkat J, Sekulla C, Brauckhoff K, et al. Multiple endocrine neoplasia 2B syndrome due to codon 918 mutation: clinical manifestation and course in early and late onset disease. World J Surg. 2004;28:1305-11.

28. Ezabella MC, Hayashida CY, Bisi H, Leite MO, Borelli A, Abelin NM, et al. Early detection of medullary thyroid carcinoma in multiple endocrine neoplasia type II. Rev Hosp Clin Fac Med Sao Paulo. 1990;45:105-9.
29. Toledo SPA, Ferraz AR. Multiple endocrine type II neoplasm. Rev Hosp Clin Fac Med Sao Paulo. 1990;45:1-2.

30. Hayashida CY, Alves VAF, Kanamura CT, Ezabella MCL, Abelin NMA, Nicolau W, et al. Immunohistochemistry of medullary thyroid carcinoma and C-cell hyperplasia by an affinity-purified anti-human calcitonin antiserum. Cancer. 1993;72:1356-63.

31. Livolsi VA. C cell hyperplasia/neoplasia. J Clin Endocrinol Metab. $1997 ; 82: 39-41$

32. Bachelot A, Lombardo F, Baudin E, Bidart JM, Schlumberger M. Inheritable form of medullary thyroid carcinoma. Biochimie. 2002;89:61-6.

33. Maciel RMB. Tumorigênese Molecular Tiroideana: Implicações Para a Prática Médica. Arq Bras Endocrinol Metab. 2002;46:381-90.

34. Leboulleux S, Baudin E, Travagli JP, Schlumberger M. Medullary thyroid carcinoma. Clin Endocrinol. 2004;61:299-310.

35. Xing S, Smanik PA, Oglesbee MJ, Trosko JE, Mazzaferri EL, Jhiang SM. Characterization of RET oncogenic activation in MEN2 inherited cancer syndromes. Endocrinology. 1996;137:1512-19.

36. Abelin NMA, Gomes S, Ivanoff MT, Ezabella MCL, Hayashida CY, Toledo SPA. Abordagem clínica e laboratorial do bócio uni-nodular sólido: vantagens da determinação da calcitonina sérica por métodos distintos. Arq Bras Endocrinol Metab. 1999;43:104-13.

37. Martin RC, Ezabella MC, Toledo SPA. Calcitonin levels in tissue culture of thyroid medullary carcinoma. Rev Hosp Clin Fac Med Sao Paulo. 1985;40:220-2.

38. Martin RC, Toledo SPA. Dynamics of calcitonin secretion in tissue culture of medullary thyroid carcinoma. Rev Hosp Clin Fac Med Sao Paulo. 1989;44:36-9.

39. Randolph GW, Maniar D. Medullary carcinoma of the thyroid. Cancer Control. 2000;7:253-61.

40. Machens A, Gimm O, Hinze R, Höppner W, Boehm BO, Dralle H. Genotype-phenotype correlations in hereditary medullary thyroid carcinoma: oncological features and biochemical properties. J Clin Endocrinol Metab. 2001;86:1104-9.

41. Carney JA, Sizemore GW, Sheps SG. Adrenal medullary disease in multiple endocrine neoplasia type 2. Pheocromocytoma and its precursors. Am J Clin Pathol. 1976;66:279-90.

42. Dahia PL, Aguiar RC, Tsanaclis AM, Bendit I, Bydlowski SP, Abelin NM, et al. Molecular and immunohistochemical analysis of P53 in phaeochromocytoma. Br J Cancer. 1995;72:1211-3.

43. Eng C, Crossey PA, Mulligan LM, Healey CS, Houghton C, Prowse A, et al. Mutations in the RET proto-oncogene and the von Hippel-Lindau disease tumour suppressor gene in sporadic and syndromic phaeochromocytomas. J Med Genet. 1995;32:934-7.

44. Aguiar RC, Dahia PL, Sill H, Toledo SPA, Goldman JM, Cross NC. Deletion analysis of the p16 tumour suppressor gene in phaeochromocytomas. Clin Endocrinol (Oxf). 1996;45:93-6.

45. Dahia PL, Toledo SPA, Mulligan LM, Maher ER, Grossman AB, Eng C. Mutation analysis of glial cell line-derived neurotrophic factor (GDNF), a ligand for the RET/GDNF receptor alpha complex, in sporadic phaeochromocytomas. Cancer Res. 1997;57:310-3. 
46. Duerr EM, Gimm O, Neuberg DS, Kum JB, Clifford SC, Toledo SPA, et al. Differences in allelic distribution of two polymorphisms in the VHLassociated gene CUL2 in pheochromocytoma patients without somatic CUL2 mutations. J Clin Endocrinol Metab. 1999;84:3207-11

47. Ichihara M, Murakumo Y, Takahashi M. RET and neuroendocrine tumors. Cancer Letters. 2004;204:197-211.

48. Dahia PL, Ross KN, Wright ME, Hayashida CY, Santagata S, Barontini $\mathrm{M}$, et al. A HIF1alpha regulatory loop links hypoxia and mitochondrial signals in pheochromocytomas. PLoS Genet. 2005;1:72-80.

49. Herfarth KK, Bartsch D, Doherty GM, Wells SA, Lairmore TC. Surgical management of hyperparathyroidism is patients with multiple endocrine neoplasia type 2A. Surgery. 1996;120:966-74.

50. Wells SA Jr, Chi DD, Toshimak, et al. Predictive DNA testing and prophylactic thyroidectomy in patients at risk for multiple endocrine neoplasia type 2A. Ann Surg. 1994;220:237-50.

51. Martucciello G, Ceccherini I, Lerone M, Jasonni V. Pathogenesis of Hirschsprung's disease. J Pediat Surg. 2000;35:1017-25.

52. Nunes AB, Ezabella MCL, Pereira AC, Krieger JE, Toledo SPA. A novel Val648Ile substitution in RET protooncogene observed in a Cys634Arg multiple endocrine neoplasia type $2 \mathrm{~A}$ kindred presenting with an adrenocorticotropin-producing pheochromocytoma. J Clin Endocrinol Metab. 2002;87:5658-61.

53. Puñales MK, Rocha PA, Gross JL, Maia AL. Carcinoma Medular de Tireóide: Aspectos Moleculares, Clínico-Oncológicos e Terapêuticos. Arq Bras Endocrinol Metab. 2004;48:137-46.

54. Mulligan LM. Multiple endocrine neoplasia type 2: molecular aspects. Front Horm Res. 2001;28:81-102.

55. Carlomagno F, Melillio RM, Visconti R, Salvatore G, De Vita G, Lupoli $\mathrm{G}$, et al. Glial cell line-derived neurotrophic factor differentially stimulates ret mutants associated with the multiple endocrine neoplasia type 2 syndromes and hirschsprung disease. Endocrinology. 1998;139:3613-9.

56. Eng C, Smith DP, Mulligan LM, Nagai MA, Healey CS, Ponder MA, et al. Point mutation within the tyrosine kinase domain of the RET protooncogene in multiple endocrine neoplasia type 2B and related sporadic tumours. Hum Mol Genet. 1994;3:237-41.

57. Puñales MK, Graf H, Gross JL, Maia, AL. RET codon 634 mutations in multiple endocrine neoplasia type 2: Variable clinical features and clinical outcome. J Clin Endocrinol Metab. 2003;88:2644-49.

58. Niccoli-Sire P, Murat A, Baudin E, Henry J, Proye C, Bigorgne J, et al. Early or prophylatic thyroidectomy in MEN2/FMTC gene carriers: results in 71 thyroidectomized patients. Eur J Endocrinol. 1999;141:46874 .

59. Puñales MK, Graf H, Gross JL, Maia AL. Rastreamento Genético do Carcinoma Medular de Tireóide: Identificação de Mutações no Protooncogene RET. Arq Bras Endocrinol Metab. 2002;46:632-39.

60. Nunes AB. Identificação de mutações do proto-oncogene RET associadas à forma hereditária do carcinoma medular de tireóide. 2001; Tese de Doutoramento, Departamento de Clínica Médica, FMUSP.

61. Lombardo F, Baudin E, Chiefari E, Arturi F, Bardet S, Caillou B, et al. Familial medullary thyroid carcinoma: clinical variability and low aggressiveness associated with RET mutation at codon 804. J Clin Endocrinol Metab. 2002;87:1674-80.
62. Edery P, Lyonnet S, Mulligan LM, Pelet A, Dow E, Abel L, et al Mutations of the RET proto-oncogene in Hirschsprung's disease. Nature. 1994;367:378-80.

63. Eng C, Mulligan LM. Mutations of the RET proto-oncogene in the multiple endocrine neoplasia type 2 syndromes, related sporadic tumours, and hirschsprung disease. Hum Mutat. 1997;9:97-109.

64. Berndt I, Reuter M, Saller B, Frank-Raue K, Groth P, Grubendorf M, et al. A new hot spot for mutations in the ret proto-oncogene causing familial medullary thyroid carcinoma and multiple endocrine neoplasia type 2A. J Clin Endocrinol Metab. 1998;83:770-74.

65. Silva AMA, Maciel RMB, Silva MRD, Toledo SRC, Carvalho MB, Cerutti JM. A novel germ-line mutation in RET exon 8 (Gly533Cys) in a large kindred with familial medullary thyroid carcinoma. J Clin Endocrinol Metab. 2003;88:5438-43.

66. Gimm O, Marsh DJ, Andrew SD, Frilling A, Dahia PL, Mulligan LM, et al. Germline dinucleotide mutation in codon 883 of the RET protooncogene in multiple endocrine neoplasia type 2B without codon 918 mutation. J Clin Endocrinol Metab. 1997;82:3902-4.

67. Kahraman T, Groot JWB, Rouwe C, Hofstra RMW, Links TP, Sijmons $\mathrm{RH}$, et al. Acceptable age for prophylatic surgery in children with multiple endocrine neoplasia type 2A. Eur J Surg Oncol. 2002;29:33135

68. Cranston AN, Ponder BAJ. Modulation of medullary thyroid carcinoma penetrance suggests the presence of modifier genes in a RET transgenic mouse model. Cancer Research. 2003;63:4777-80.

69. Miller S, Dykes D, Poleski H. A simple salting out procedure for extracting DNA from human nucleated cells. Nucleic Acids Res. $1988 ; 16: 1215$

70. Saiki RK, Gelfand DH, Stoffel S, Scharf SJ, Erlich HA. Primer-directed enzymatic amplification of DNA with a thermostable DNA polymerase. Science. 1988;239:487-91.

71. Sanger F \& Coulson AR. A rapid method for determining sequences in DNA by primed synthesis with DNA polymerase. J Mol Biol. 1975;94:444-48.

72. Sheffield VC, Cox DR, Lerman LS, Myers RM. Attachment of a 40base pair $\mathrm{G}+\mathrm{C}$ rich sequence (GC-clamp) to genomic DNA fragments by the polymerase chain reaction results in improved detection of singlebase changes. Proc Natl Acad Sci (USA). 1989;86:232-36.

73. Blank RD, Skalr CA, Martin ML. Denaturing gel electrophoresis to diagnose multiple endocrine neoplasia type 2. Clin Chem. 1996;42:598603

74. Decker RA, Peacock ML. Update on the profile of multiple endocrine neoplasia type 2A RET mutations: Practical issues and implications for genetic testing. Cancer. 1997;80:557-68.

75. Wu Y, Hayes VM, Osinga J, Mulder IM, Loomam MWG, Buys CHCM, et al. Improvement of fragment and primer selection for mutation detection by denaturing gradient gel electrophoresis. Nucleic Acids Res. 1998;26:5432.

76. Wu Y, Stulp RP, Elfferich P, Osinga J, Buys CHCM, Hofstra RMW. Improved mutation detection in GC-rich DNA fragments by combined DGGE and CDGE. Nucleic Acids Res. 1999;27:e9.

77. Frediani D. 2002; Rastreamento Gênico através de Enzimas de Restrição na forma Hereditária do Carcinoma Medular de Tireóide. Monografia, Departamento de Clínica Médica, FMUSP. 
78. Marsh DJ, Robinson BG, Andrew S, Richardson AL, Pojer R, Schnitzler $\mathrm{M}$, et al. A rapid screening method for the detection of mutations in the RET proto-oncogene in multiple endocrine neoplasia type $2 \mathrm{~A}$ and familial medullary thyroid carcinoma families. Genomics. 1994;23:4779.

79. Eng C. Multiple endocrine neoplasia type 2 and the practice of molecular medicine. Rev in Endocrinol Dis. 2000;1:283-90.
80. Bugalho MJ, Domingues R, Sobrinho L. Molecular diagnosis of multiple endocrine neoplasia type 2. Expert Ver Mol Diagn 2003;3:769-79.

81. Szinnai G, Meier C, Komminoth P, Zumsteg UW. Review of multiple endocrine neoplasia type $2 \mathrm{a}$ in children: therapeutic results of early thyroidectomy and prognostic value of codon analysis. Pediatrics. 2004;111:E132-40. 